\title{
Effect of Integrated Nutrient Management on Soil Nutrient Status, Fruit Quality and Yield of Mandarin Orange (Citrus reticulata) in Darzo, Mizoram
}

\author{
Timothy Lalrinfela* and Zosangliani Varte
}

Krishi Vigyan Kendra Lunglei District, Mizoram, India

*Corresponding author

Keywords

Nutrients, orchard, parameters, organic, yield

Article Info

Accepted:

22 April 2021

Available Online:

10 May 2021

\section{A B S T R A C T}

Frontline demonstration was carried out at farmers' orchard of Darzo Village, Mizoram during the year 2019 - 2020 to evaluate the effect of nutrient input on the yield characters of Mandarin orange and its impact on soil health. Demonstrated and control plots were assigned at farmers orchard. Soil test base nutrients were applied as NPK 0.700, 0.400, 0.500 $\mathrm{kg}$ in the form of urea, SSP and MOP per tree, slaked lime $3 \mathrm{~kg}$ per tree and farm yard manure $5 \mathrm{~kg}$ per tree, meanwhile control plots were maintained at the orchard. Studies revealed that fruit physical and quality parameters were enhanced with the application of balance nutrients. Soil physicochemical properties - soil organic carbon, available nitrogen and available phosphorus content of the soil increases with integrated nutrient application, which resulted to increase in yield of fruits. Decrease in soil reaction was due to application of organic inputs.

\section{Introduction}

Mandarin orange (Citrus reticulata Blanco.) is an important commercial fruit crops which belongs to family Rutaceae. Among fruit crops in Lunglei District Mizoram, Mandarin orange occupies maximum areas because of its socio economic important and grown in the area of 776.77 ha with the production of 493.19 MT (as per 2020 Dept. of Horticulture) and the farmers cultivate Mandarin orange as a sole crop or intercropped with some other crops but the productivity is low due to Citrus decline and it has become a major problem in the district and the production has been decrease year by year due to combined effect of abiotic and biotic factors. This low productivity is due to negligence and malnutrition of the citrus orchards.

Citrus is very much responsive to application of manures and fertilizers. A proper application of balanced fertilizer promotes thick, green and sustainable orchard and 
Mandarin orange received $60 \%$ of their required nutrients from chemical fertilizer and 40\% from Farm Yard Manure (FYM), and found best with yield and qualitative parameters. The production of Citrus fruit can be increased by proper supply of nutrients and integrated nutrient management in citrus help to maintain soil fertility and plant nutrient supply to optimum level for sustaining citrus productivity through optimization of the benefits from all possible sources of plant nutrients in an integrated manner. The main objective of this study is to standardize the nutritional requirement necessary for sustainable fruit production.

\section{Materials and Methods}

The study was under Frontline demonstration (FLD) programme of KVK Lunglei, Mizoram carried out during 2019-2020. FLD was conducted at Darzo village covering an area of 20 ha. On the basis of the farmers problems, FLD on mandarin orange was proposed in the annual action plan of Krishi Vigyan Kendra Lunglei district during the year 2019-20 in one village, Darzo under one blocks- Hnahthial.

The FLD programme with full package of practice covered 27orange growers during the year 2019-20. Individual demonstration area varied from 0.4 to 0.8 ha while the total area was 20 ha. Most of the participating farmers kept a control plot for comparison. As an initiation slaked lime, urea $(46 \% \mathrm{~N}), \mathrm{SSP}(22 \%$ $\left.\mathrm{P}_{2} \mathrm{O}_{5} ; 12 \% \quad \mathrm{~S}\right)$ and MOP $\left(60 \% \quad \mathrm{~K}_{2} \mathrm{O}\right)$ was provided to farmers. Lime and organic nutrient (FYM) was applied at $3 \mathrm{~kg}$ and $5 \mathrm{~kg}$ per tree, respectively.

Based on soil test result, nutrients were recommended as NPK per tree in the form of urea $1.5 \mathrm{~kg}$, SSP $2 \mathrm{~kg}$ and MOP $0.8 \mathrm{~kg}$ per tree. Slaked lime 500gm was applied at March around the tree mixing properly with the soil and nutrients were applied in two split doses at
March and August. Micronutrient spray was applied in the month of May. To determine soil physico-chemical properties, soil samples were collected at a depth of $15-20 \mathrm{~cm}$ before and after treatment of the plant. The soil samples were air dried at room temperature. Soil samples before chemical analysis was screened through a $2 \mathrm{~mm}$ sieve. Important parameters to be assessed are as follows:

\section{Physical Parameters}

\section{Size of the Fruits}

Data was recorded from single branch by tagging it, all over the period from eastern aspect. Fruit size data was recorded during harvesting time, from three fruits of each replication $\left(15^{\text {th }}\right.$ November). The fruit size (diameter) was recorded by manual vernier caliper.

\section{Fruits Weight}

From the tagging branches single fruits were harvested from each treatment (plant) and final fruit weighs by digital weight balance in gram.

\section{Peel Weight}

Peel of fruits were separated and weighed by using digital weighing balance. The weight was expressed in gram.

\section{Number of Seeds}

Number of seeds from the harvested fruits accordingly from treatment and replication was counted in a numbers.

\section{Numbers of Segments}

The segment of the sampled fruit was counted and expressed in number. 


\section{Yield of fruit}

Total yield of the fruit was expressed in $\mathrm{kg}$ per tree

\section{Total Soluble Solid}

Total Soluble Solid (TSS) was measured by hand held refractometer at room temperature of $20^{\circ} \mathrm{C}$ and expressed in degree brix. To obtain accurate readings at temperature measurement was performed at day hours at $20{ }^{\circ} \mathrm{C}$.

\section{Soil Physico-chemical Properties}

\section{Soil Organic Carbon}

The total organic carbon (TOC) content of finely ground sample was determined by Walkely and Black's Wet Oxidation method as describe by Jackson (1973) and expressed in percentage $(\%)$

\section{Soil pH}

The $\mathrm{pH}$ of soil samples were measured in 1 : 2.5 soil: distilled water suspension by potentiometric method using glass electrode Jackson (1973).

\section{Available Nitrogen}

Available nitrogen was determined by modified alkaline permanganate method of Subbiah and Asija (1956) and total nitrogen content was determined by Micro-Kjeldahl Method describe by Jackson (1973). It is expressed in $\mathrm{Kgha}^{-1}$.

\section{Available Phosphorus}

Available phosphorus was determined by the method as describe Bray and Kurt z (1945). It is expressed in $\mathrm{Kgha}^{-1}$.

\section{Available Potassium}

Available potassium was extracted with neutral normal ammonium acetate and the content of potassium in the solution was estimate $\mathrm{d}$ by Flame photometer (Jackson, 1973). It is expressed in $\mathrm{Kgha}^{-1}$.

\section{Results and Discussion}

\section{Fruit set and Yield}

The integrated nutrient management influenced the fruit set and fruit yield. The increase in average number of fruits was much higher in demonstration than in control (Table 1). The increase in both fruit number and fruit weight might be attributed to the fact that, there was increase in level of nutrients NPK in assimilating area of crop due to which the rate of dry matter production was enhanced. Similarly, due to rational partitioning of dry matter to economic sink, the yield attributes were improved. The above results are in conformity with the findings of Dalal et al., (2004). The maximum fruit weight $(142.85 \mathrm{gm})$, fruit length $(6 \mathrm{~cm})$, fruit breadth $(5 \mathrm{~cm})$ were recorded with the demonstrated technology NPK at a rate of $0.700,0.400$, $0.500 \mathrm{~kg}$ per tree [urea $1.5 \mathrm{~kg}$, SSP $2 \mathrm{~kg}$ and MOP $0.8 \mathrm{~kg}$ per tree in two split doses]. This might be due to good nutrient status, improved plant conditions, efficient functioning of leaf area and increased photosynthetic activity. These results are in conformity with the results obtained by Singh and Banik (2011) in sweet orange. The improvement in quality of fruits may be due to the proper supply of nutrients and induction of hormones, which enhances cell division and elongation, larger size and weight of fruits, better root development, better water uptake and deposition of nutrients. It may also be due to the increased $\mathrm{N}$ addition and the catalytic activity of several enzymes (Rosangpuii et al., 2019). 
A high TSS of $12.5\left({ }^{\circ} \mathrm{Brix}\right)$ was observed as compared to 10 ( $\left.{ }^{\circ} \mathrm{Brix}\right)$ in case of control. This may be attributed to its relation with nitrogen content of the in mandarin orange. High dose of nitrogen (1.5 kg urea per tree) application increases total soluble solid (TSS) up to a certain limit (Zerki, 2011). With increases in total soluble solid in mandarin fruit, it decreases titratable acidity of juice (Aular, Casares, \& Natale, 2017). Similarly, phosphorous enhances higher sugar to acid ratio in citrus fruit (Ritenour et al., 2003).Increase in peel weight, number of segments and number of seed per segment was observed from 20gm, 8 numbers and 2 numbers in control as compared to $23.3 \mathrm{gm}$, 11 number and 3.5 number in demonstrated yield. This was due to increase in fruit size as affected by application of phosphorus and potassium. Similar finding was reported by Quaggio et al., 2002.

Application of nitrogen resulted in vigorous vegetative growth of the plant and gave dark green colour of the foliage. This favoured the photosynthetic activity of the plants and greater synthesis of carbohydrate, which led to the formation of amino acids, nucleoproteins, chlorophyll, alkaloids and amides.

These complex compounds were responsible for building up of new tissues and were associated with a number of metabolic processes, which in turn favoured better development of plants. The increase in growth as a result of nitrogen application is obvious. Similarly, increase in vegetative growth of fruit plants by the application of nitrogen has also been reported earlier by Kaul and Bhatnagar (2006)in Kinnow mandarin.

\section{Soil physico-chemical properties}

Decrease in soil $\mathrm{pH}$ from 6.6 to 5.2 was observed in the final reading, Table 2 . This might be due to application of farm yard manure, which could improve soil acidity by increasing the soil organic matter, promoting the soil maturation, improving the soil structure, and enhancing the soil base saturation percentage, which is in line with the finding of Zhang et al., (2009) and Li et al., (2010). Increase in soil organic carbon (SOC) from $0.94 \%$ to $1.12 \%$ was observed, which is beneficial for accumulation of soil organic matter and improves soil fertility.

This may be because both the application of organic manure and chemical fertilizer can improve soil aggregation, soil water retention, and reduce bulk density of the soil, promoting crop growth and the return of more root residues to the soil, Hyvo"nen et al., (2008).

Available nitrogen in medium range was found to be higher $\left(277 \mathrm{~kg} \mathrm{ha}^{-1}\right)$ in final reading after nutrient application, than in the initial reading $235 \mathrm{~kg} \mathrm{ha}^{-1}$.

$\mathrm{N}$ source of nutrient might have produced more residual $\mathrm{N}$ in soil. Increase in amount of available $\mathrm{N}$ for plant is because of organic matter, acidic $\mathrm{pH}$ and proper moisture in soil (Zupanc and Zupancic, 2010). Available $\mathrm{P}_{2} \mathrm{O}_{5}$ was found to decrease from $94.73 \mathrm{~kg} \mathrm{ha}^{-1}$ to $55.41 \mathrm{~kg} \mathrm{ha}^{-1}$.

This may be attributed to the $\mathrm{pH}$ condition that had influenced the conversion of Al-P and Fe$\mathrm{P}$ towards available $\mathrm{P}$. Maximum available $\mathrm{P}$ was also found in a $\mathrm{pH}$ ranged between 5.5 and 6.5. $\mathrm{P}$ availability in most soils is at a maximum near pH 6.5 (Havlin et al., 2007). A decline in available $\mathrm{K}_{2} \mathrm{O}$ was observed, Table 2.

This might be due to its involvement in synthesis and transport of photosynthates to plant reproductive and storage organ like fruits, which is evident from the increase in yield from 14 tha $^{-1}$ to 25 tha $^{-1}$. Similar finding was reported by Quaggio et al., (2002). 
Table.1 Effect on fruit physical and quality parameters

\begin{tabular}{|c|c|c|c|c|c|c|c|c|c|}
\hline $\begin{array}{c}\text { Treatme } \\
\text { nts }\end{array}$ & $\begin{array}{c}\text { Average } \\
\text { fruit } \\
\text { length } \\
\text { (cm) }\end{array}$ & $\begin{array}{c}\text { Aver } \\
\text { age } \\
\text { Yield } \\
\text { (t/ha) }\end{array}$ & $\begin{array}{c}\text { Average } \\
\text { fruit } \\
\text { breath } \\
\text { (cm) }\end{array}$ & $\begin{array}{c}\text { Average } \\
\text { fruit } \\
\text { weight } \\
\text { (gm) }\end{array}$ & $\begin{array}{c}\text { Average } \\
\text { no. of } \\
\text { fruit per } \\
\text { plant }\end{array}$ & $\begin{array}{c}\text { Peel } \\
\text { weight } \\
\text { (gm) }\end{array}$ & $\begin{array}{c}\text { No. of } \\
\text { segment }\end{array}$ & $\begin{array}{c}\text { No. of } \\
\text { seed per } \\
\text { segment }\end{array}$ & $\begin{array}{c}\text { TSS } \\
\left({ }^{\circ} \text { Brix) }\right.\end{array}$ \\
\hline $\begin{array}{c}\text { Demons } \\
\text { trated }\end{array}$ & 6 & 25 & 5 & 142.85 & 1500 & 23.3 & 11 & 3.5 & 12.5 \\
\hline Control & 4.5 & 14 & 4 & 121 & 670 & 20 & 8 & 2 & 10 \\
\hline
\end{tabular}

Table.2 Effect on soil physico-chemical properties

\begin{tabular}{|c|c|c|c|c|c|}
\hline Soil test & $\begin{array}{l}\text { Soil organic } \\
\text { carbon }(\%)\end{array}$ & Soil pH & $\begin{array}{c}\text { Available } \\
\text { Nitrogen } \\
\text { (Kg/ha) }\end{array}$ & $\begin{array}{c}\text { Available } \\
\mathbf{P}_{2} \mathbf{O}_{5} \\
(\mathbf{K g} / \mathbf{h a})\end{array}$ & $\begin{array}{c}\text { Available } \\
\mathbf{K}_{2} \mathrm{O} \\
(\mathbf{K g} / \mathbf{h a})\end{array}$ \\
\hline Initial & 0.94 & 6.5 & 235 & 94.73 & 303.1 \\
\hline Final & 1.12 & 5.2 & 277 & 55.41 & 132.6 \\
\hline
\end{tabular}

The integrated nutrient management in mandarin orange is an efficient way to supply nutrient requirement which reduce its sole dependence on inorganic fertilizers. Besides, it also improves soil nutrient status which ultimately results in quality fruit production. Application of organic input farm yard manure has improves soil properties which led to availability of important available soil nutrient like available nitrogen and phosphorus ultimately leading to improve in yield and fruit set.

\section{Acknowledgements}

The author is thankful to ICAR-ATARI ZONE VII Bharapani, Meghalaya forfinancial assistance.

\section{References}

Aular, J., Casares, M., \& Natale, W. (2017). Factors affecting citrus fruit quality: Emphasis on mineral nutrition. Científica, 45(1), 64-72.

Black, C. A. (1965). Methods of soil analysis. Part II. American society of agronomy, Madison, Wisconsin, USA.
Bray, R. H. and Kurtz, L. T. (1945). Determination of total organic and available forms of phosphorus in soils. Soil Sci. 59 : 39-46.Deenik, J. (2006). Nitrogern mineralization potential in important agricultural soils of Hawaii.Soil and Crop Management 15, Cooperative extension service, University of Hawaii at Manoa.

Dalal, S. R., Gonge, V. S., Jogdande N. D and Moharia A. 2004. Response of different levels of nutrients and PSB on fruit yield and economics of citrus. PKV Research Journal 28:126-128.

Havlin, J. L.; Beaton, J. D.; Tisdale, S. L. and Nelson, W. L. (2007). Soil fertility and fertilizers. Seventh edition, PHI Learning (India) Pvt. Ltd.

Hyvo“nen R., Persson T., Andersson S., Olsson B., Agren GI, et al., (2008) Impact of long-term nitrogen addition on carbon stocks in trees and soils in northern Europe. Biogeochemistry 89: 121-137.

Jackson, M. L. (1973). Soil chemical analysis. Prentice Hall of India Pvt. Ltd., New Delhi.

Kaul M. K. and Bhatnagar P. 2006. 
Nutritional studies in kinnow. Indian Journal of Arid Horticulture 1(1): 2324.

Li B. Y., Huang S. M., Wei M. B., Zhang H. L., Shen A. L., et al., (2010) Dynamics of soil and grain micronutrients as affected by long-term fertilization in an aquicInceptisol. Pedosphere 20: 725-735.

Quaggio J. A., Mattos D. Jr., Cantarella H., Almeida E. L. E., Cardoso S.A.B., Lemon yield and fruit quality affected by NPK fertilization, Sci. Hortic. 96 (2002) 151-162.

Ritenour, M., Wardowski, W. F., \& Tucker, D. P.H. (2003). Effects of water and nutrients on the postharvest quality and shelf life of citrus. Florida: University of Florida Cooperative Extension Service, Institute of Food and Agricultural Sciences, EDIS.

Rosangpuii P., Barun S., Jes L. \& Lalthamawii, (2019) Effect of Organic Manures on Growth, Yield and Quality of Assam Lemon [Citrus limon (L.) Burm]. Int.J.Curr.Microbiol.App.Sci (2019) 8(9): 1009-1019
Singh S R and Banik B C. 2011. Response of integrated nutrient management on flowering, fruit setting, yield and fruit quality in sweet orange (Citrus sinensis). Asian Journal of Horticulture 6(1): 151- 154.

Subbiah, B. V. and Asija, G. L. (1956).A rapid procedure for determination of available nitrogen in soils. Current science. $25: 259-260$

Zekri, M., Obreza, T. A., Koo, R. \& Alferez, F. M. (2003). Irrigation, nutrition, and citrus fruit quality.Institute of Food and Agricultural Sciences (IFAS), University of Florida.Retrieved from https://edis.ifas.ufl.edu/pdf files/SS/SS42600.pdf.

Zhang H. M., Wang B. R., Xu M. G., Fan T. L. (2009) Crop yield and soil responses to long-term fertilization on a red soil in southern China. Pedosphere 19: 199-207.

Zupanc, V. and J. M. Zupanc, 2010. Changes in soil characteris-tics during landfill leachate irrigation of Populus deltoids. Waste Management, 30: 2130 -2136.

\section{How to cite this article:}

Timothy Lalrinfela and Zosangliani Varte. 2021. Effect of Integrated Nutrient Management on Soil Nutrient Status, Fruit Quality and Yield of Mandarin Orange (Citrus reticulata) in Darzo, Mizoram. Int.J.Curr.Microbiol.App.Sci. 10(05): 709-714. doi: https://doi.org/10.20546/ijcmas.2021.1005.079 